\title{
Use of molecular markers for species identification of Korean Perkinsus sp. isolated from Manila clams Ruditapes philippinarum
}

\author{
Kyung-Il Park ${ }^{1}$, Joong-Ki Park ${ }^{2}$, Jehee Lee ${ }^{1}$, Kwang-Sik Choi ${ }^{1, *}$ \\ ${ }^{1}$ School of Applied Marine Science, College of Ocean Science, Cheju National University, 1 Ara 1-Dong Jeju City, \\ Jeju 690-756, Republic of Korea \\ ${ }^{2}$ Department of Parasitology and Medical Research Institute, College of Medicine, Chungbuk National University, Chongju, \\ Chungbuk 361-763, Republic of Korea
}

\begin{abstract}
Perkinsus is the pathogen responsible for mass mortality of the Manila clam Ruditapes philippinarum. Perkinsus sp. isolated from Manila clams collected in Korean waters was assayed by polymerase chain reaction (PCR) to determine its phylogenetic affinity with other congeneric species. Regions of rRNA of Perkinsus sp. isolated from clam haemolymph were cloned and sequenced. Sequences of a non-transcribed spacer (NTS), internal transcribed spacers (ITS 1,2) and 5.8S rRNA genes were compared to those available from other Perkinsus species. The NTS sequence of Korean Perkinsus was approximately 99.9 to $100 \%$ similar to that of $P$. atlanticus and 98.06 to $98.15 \%$ and 73.05 to $73.14 \%$ similar to those of $P$. olseni and $P$. marinus, respectively. The ITS $1,5.8$ S rRNA and ITS 2 sequences of Korean Perkinsus showed $100 \%$ similarity to P. atlanticus and Perkinsus sp. reported from Japan. The ITS-5.8S rRNA sequences of Korean Perkinsus were 99.86 and $93.73 \%$ similar to those of $P$. olseni and $P$. marinus, respectively. The sporulation pattern and morphology of the Korean Perkinsus were very similar to those of P. atlanticus. Our data suggest that the Perkinsus sp. isolated from clams in Korean waters is $P$. atlanticus, which is currently synonymous with $P$. olseni reported from Australia. By considering that $P$. olseni has taxonomic priority, Korean Perkinsus sp. is accepted as P. olseni (atlanticus).
\end{abstract}

KEY WORDS: NTS $\cdot$ ITS $\cdot 5.8 \mathrm{~S}$ rRNA $\cdot$ Perkinsus olseni (atlanticus) $\cdot$ Ruditapes philippinarum · Taxonomy $\cdot$ Korea

- Resale or republication not permitted without written consent of the publisher

\section{INTRODUCTION}

The Manila clam (also known as the little-neck or short-neck clam) Ruditapes philippinarum is one of the most common marine animals on sandy beaches and tidal flats along the coast of Korea, Japan and China. Owing to its fast growth and high productivity, this clam has been cultured commercially on the western and southern coasts of Korea (Lee et al. 1996, Chung et al. 2001). Over the past decade, clam harvests in Korea have declined dramatically as a result of recurrent mass mortalities during late summer and early fall. Several studies of clam mortalities have reported a high level of Perkinsus sp. infection, suggesting that Perkinsus sp. is responsible for the mortalities, as has been observed in other marine molluscs (Mackin \& Ray 1954, Da Ros \& Canzonier 1985, Azevedo et al. 1990, Park \& Choi 2001).

Since the first report of Perkinsus marinus (formerly Dermocystidium marinum) from the American oyster Crassostrea virginica in the Gulf of Mexico (Mackin et al. 1950), several species of Perkinsus have been identified in various marine molluscs, including $P$. olseni in the Australian black lip abalone Haliotis rubra (Lester \& Davis 1981), P. atlanticus in the carpet shell clam Ruditapes decussatus in Portugal (Azevedo 1989), 
P. qugwadi in the Japanese scallop Patinopecten yessoensis on the west coast of Canada (Blackbourn et al. 1998), and P. andrewsi in the Baltic clam Macoma balthica (Coss et al. 2001) and P. chesapeaki in the softshell clam Mya arenaria (McLaughlin et al. 2000), both in Chesapeake Bay, USA. Casas et al. (2004) recently reported a new species of Perkinsus, P. mediterraneus, from the European flat oyster Ostrea edulis from the Balearic Islands in the Mediterranean Sea.

Unidentified Perkinsus species have been isolated from Ruditapes philippinarum along the coasts of Korea and Japan (Choi \& Park 1997, Choi et al. 1998, Hamaguchi et al. 1998, Park \& Choi 2001, Choi et al. 2002), as well as along the north-eastern coast of China, in the Yellow Sea (Liang et al. 2001). Hamaguchi et al. (1998) analysed the nucleotide sequences of 2 internal transcribed spacers (ITS 1 and ITS 2) and 5.8S rRNA of Perkinsus isolated from clams in Kumamoto and Hiroshima, Japan. ITS sequences of Perkinsus from Japanese clams were almost identical to those of $P$. atlanticus and $P$. olseni, suggesting that Perkinsus isolated from clams in Japan may be conspecific with, or closely related to $P$. atlanticus in European waters. Size and microscopic features of hypnospores and trophozoites of Perkinsus isolated from the Manila clam in Korea were very similar to those of P. atlanticus (Park \& Choi 2001), suggesting that Perkinsus found in Korea is also closely related to $P$. atlanticus,

One of the most conventional ways to differentiate species in the genus Perkinsus is to use several phenotypic keys, including host utilities, ultrastructure of the zoospores and pathologic attributes (Perkins 1969, Azevedo 1989). Recently, phylogenetic analysis of nucleotide sequence data has been widely used for species-level taxonomy in a number of living organisms, including Perkinsus. In particular, the NTS, ITS and 5.8S rRNA regions of Perkinsus spp. have become the most frequently used molecular marker genes for species discrimination among Perkinsus species (Goggin \& Barker 1993, Reece et al. 1997, Kotob et al. 1999a,b, Robledo et al. 1999, Figueras et al. 2000, Coss et al. 2001, Casas et al. 2002).

In the present paper, we report the species identity of Korean Perkinsus found in Ruditapes philippinarum, based on a comparative analysis of NTS, ITS 1, ITS 2 and 5.8S rDNA sequence datasets, in addition to the zoosporulation patterns of the parasite.

\section{MATERIALS AND METHODS}

In vitro culture of Perkinsus and DNA extraction. For genomic DNA preparation, Perkinsus was extracted from the haemolymph of Manila clams, Ruditapes philippinarum, collected from Wando Island (WAN) and Gomso Bay (GOM) on the southern and western coasts of Korea, respectively, where a high prevalence of Perkinsus infection has been reported (Park \& Choi 2001). Perkinsus trophozoites in the haemolymph were propagated for 1 wk in Dulbecco's Modified Eagle Medium (DMEM):Ham's F-12 (1:2), with Hepes buffer and $5 \%$ foetal bovine serum (FBS) according to Ordas \& Figueras (1998). Total genomic DNA was then extracted from in vitro-cultured Perkinsus using a commercially available DNA extraction kit (QIAGEN).

DNA sequencing and data analysis. The NTS, ITS 1, ITS 2 and 5.8S rRNA gene regions of Korean Perkinsus sp. were PCR-amplified using 2 primer sets: PKnts for the NTS region and PKits for the ITS-5.8S region (Fig. 1). The primer sequences used for PCR amplification are shown in Table 1. For PCR amplification, the reaction mixtures contained $5 \mu$ l of reaction buffer (10 mM Tris- $\mathrm{HCl}[\mathrm{pH} 9.0], 1.5 \mathrm{mM} \mathrm{MgCl}_{2}, 50 \mathrm{mM} \mathrm{KCl}$, $0.1 \%$ Triton X-100), $1 \mu \mathrm{l}$ of $10 \mathrm{mM}$ dNTP, $1 \mu \mathrm{l}$ of each primer, $1 \mu$ of Taq DNA polymerase (Promega) and $3 \mu \mathrm{l}$ of DNA template in a total volume of $50 \mu \mathrm{l}$. The reaction was carried out in a MiniCycler (MJ Research) as follows: $2 \mathrm{~min}$ at $94^{\circ} \mathrm{C}, 30$ cycles at $94^{\circ} \mathrm{C}$ for $1 \mathrm{~min}$, $58^{\circ} \mathrm{C}$ for $1 \mathrm{~min}$ and $72^{\circ} \mathrm{C}$ for $1 \mathrm{~min}$, with a final extension at $72^{\circ} \mathrm{C}$ for $5 \mathrm{~min}$. PCR products were electrophoresed in $1 \times$ TAE buffer and visualised under long-

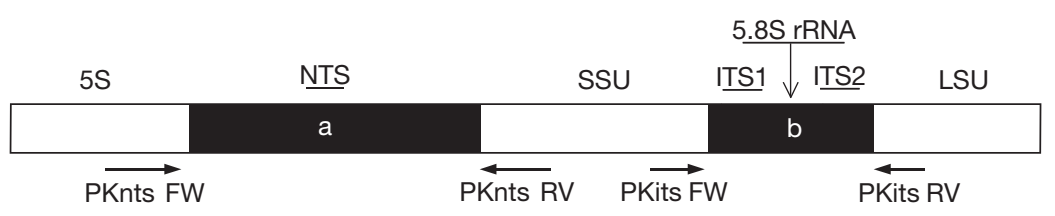

Fig. 1. Representation of the rRNA locus of Perkinsus sp. showing location of the non-transcribed spacer (NTS) domain (Region a), locations of the internal transcribed spacer (ITS 1,2) domain and the 5.8S rRNA domain (Region b), and locations of primers (horizontal arrows) used in amplification of complete sequences of NTS and ITS with 5.8S rRNA (PKnts FW, forward primer for amplification of Region $a_{i}$ PKnts RV, reverse primer for amplification of Region $a_{\text {; }}$ PKits FW, forward primer for amplification of Region b; PKits RV, reverse primer for amplification of Region b; LSU, large subunit; SSU, small subunit)

Table 1. Oligonucleotide primers used to amplify NTS and ITS 1, ITS 2 and 5.8S rRNA regions of Perkinsus sp. isolated from Ruditapes philippinarum

\begin{tabular}{|clc|}
\hline \multirow{2}{*}{ Name } & \multicolumn{1}{c}{ Primers } & Target region \\
\hline PKnts & FW: 5'-AAGTCCTTAGGGTGCTGCTGGCT-3' & NTS \\
& RV: 5'-ACTACTGGCAGGATCAACCAGGT-3' & NTS \\
PKits & FW: 5'-CTTAGAGGAAGGAGAAGTCGTAACA-3' & ITS, 5.8S rRNA \\
& RV: 5'-GCTTALTTATATGCTAAATTCAGCG-3' & ITS, 5.8S rRNA \\
\hline
\end{tabular}


wavelength UV light on a $1 \%$ agarose gel (w/v) containing ethidium bromide $(\mathrm{EtBr})$. Products were then purified using a QIAEX II gel extraction kit (QIAGEN) for cloning and sequencing. The sequencing reactions were accomplished using a Thermo Sequenase Cycler 5.5 (Amersham Pharmacia Biotech) according to the manufacturer's directions. Reaction products were purified using the ethanol precipitation method and electrophoresed on an ABI 3100 automated DNA sequencer. Sequence comparison and multiple sequence alignment for each of the NTS and ITS-5.8S rRNA regions with homologous sequences found in other Perkinsus species (Fig. 2, Table 2) were performed separately using CLUSTAL X (Thompson et al. 1994). Interspecific length heterogeneity of eukaryotic rDNA gene clusters is very common due to the high frequency of indel events during anagenetic evolutionary changes among taxa. This is especially true for the NTS and ITS regions.

To collect more informative and conserved sequence blocks from each of the NTS and ITS regions of various Perkinsus species, we also used Gblock software (Castresana 2000) with the following options for multiple alignment: a minimum of 5 sequences for a conserved position, a minimum of 7 sequences for a flank position, a maximum of 8 contiguous non-conserved positions and a minimum block length of 10 after gap cleaning for NTS. For ITS alignment, the scores 7, 11, 8 and 10 were set as each of the block parameters in the
Gblock program. To determine the taxonomic affiliation of Korean Perkinsus with other congeneric species, phylogenetic analyses for each of the NTS and ITS datasets of Perkinsus species were separately performed using the neighbour-joining (NJ) and maximum-parsimony (MP) methods in PAUP, version 4.0b8 (Swofford 1998).

In vitro sporulation. Gills of heavily infected clams collected from Wando Island were incubated in FTM for $2 \mathrm{~d}$ to induce zoospores in vitro. Hypnospores formed in FTM were harvested by centrifuging at $100 \times g$. Hypnospores were then transferred into aerated and filtered seawater fortified with antibiotics (mycostatin and chloromycetin). Hypnospores were incubated in a dark chamber at $25^{\circ} \mathrm{C}$ for 48 to $72 \mathrm{~h}$. Different cell-division stages and the occurrence of motile zoospores were examined under a light microscope. Zoospore size was measured using imageanalysis software.

\section{RESULTS}

\section{Nucleotide sequences of NTS, ITS 1, ITS 2 and 5.8S rRNA of Korean Perkinsus}

The sequences of the NTS and the ITS 1, 5.8S and ITS 2 rRNA genes of Perkinsus sp. isolated from clams collected on Wando Island, Korea, were 1147, 183, 371

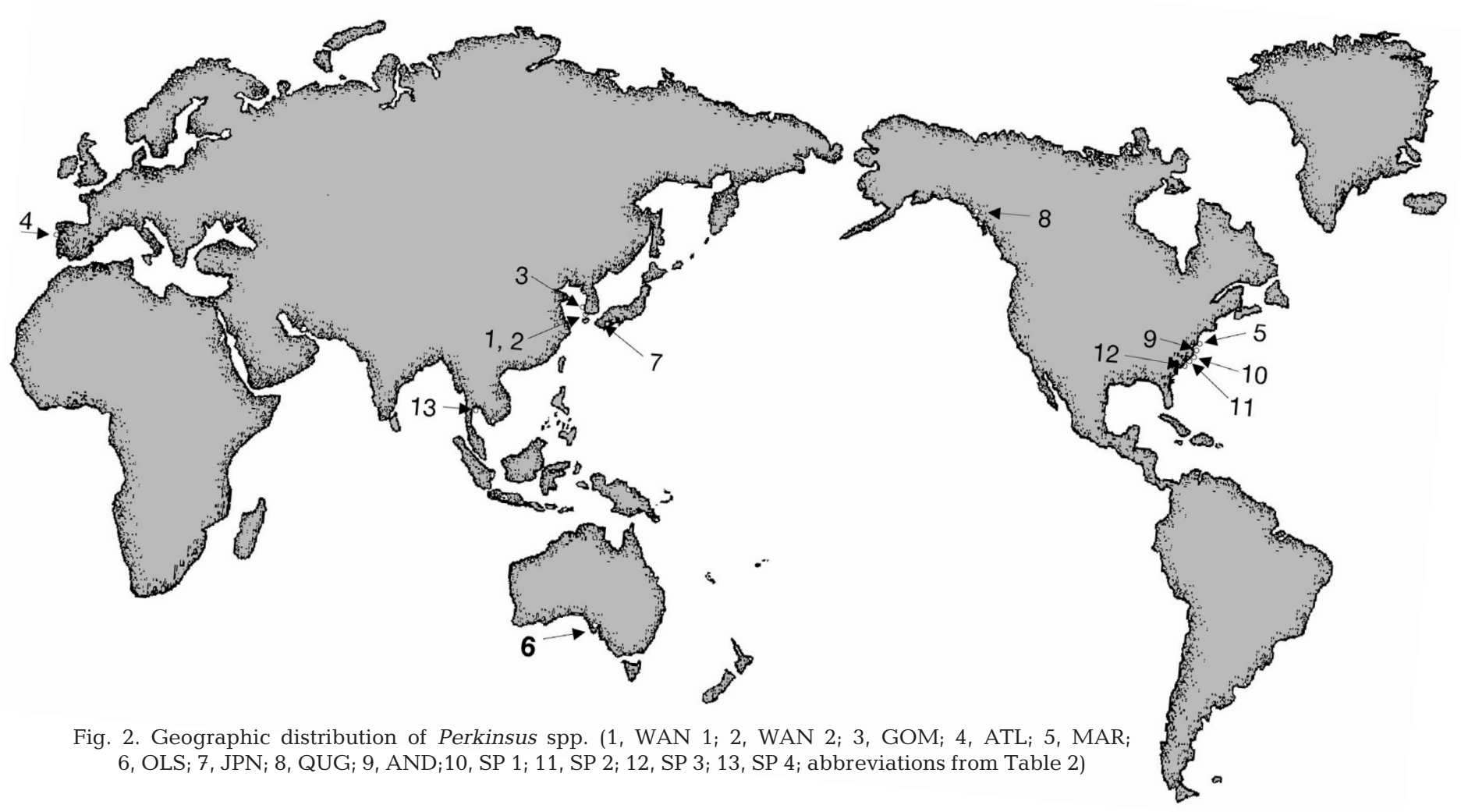


Table 2. Abbreviations, host species, geographic origins and GenBank accession numbers of Perkinsus spp. WAN1: Wando Island 1; WAN2: Wando Island 2; GOM: Gomso Bay; ATL: P. atlanticus; MAR: P. marinus; OLS: P. olensi; JPN: Perkinsus sp. from Japan QUG: P. qugwadi; AND: P. andrewsi; SP1: Perkinsus sp. 1; SP2: Perkinsus sp. 2; SP3: Perkinsus sp. 3; SP4: Perkinsus sp. 4

\begin{tabular}{|lccccc|}
\hline Organisms & Abbreviation & Host & Order of host & Location & $\begin{array}{c}\text { Accession } \\
\text { Number/Source }\end{array}$ \\
\hline Perkinsus sp. & WAN 1 & Ruditapes philippinarum & Veneroida & Korea & AF473840, AF438150 \\
Perkinsus sp. & WAN 2 & R. philippinarum & Veneroida & Korea & Present study \\
Perkinsus sp. & GOM & R. philippinarum & Veneroida & Korea & Present study \\
P. atlanticus & ATL & R. decussatus & Veneroida & Spain & AF140295 \\
P. marinus & MAR & Crassostrea virginica & Pterioida & USA & AF150986 \\
P. olseni & OLS & Haliotis laevigata & Archaeogastopoda & Australia & U07701, AF466527 \\
Perkinsus sp. & JPN & R. philippinarum & Veneroida & Japan & Hamaguchi et al. (1998) \\
P. qugwadi & QUG & Patinopecten yessoensis & Pterioida & Canada & AF151528 \\
P. andrewsi & AND & Macoma baltica & Veneroida & USA & AF102171 \\
Perkinsus sp. & SP 1 & Mercenaria mercenaria & Veneroida & USA & AF252288 \\
Perkinsus sp. & SP 2 & Mya arenaria & Veneroida & USA & AF091541 \\
Perkinsus sp. & SP 3 & Mya arenaria & Veneroida & USA & AF091542 \\
Perkinsus sp. & SP 4 & Paphia undulata & Veneroida & Thailand & AF522321 \\
\hline
\end{tabular}

and $159 \mathrm{bp}$ in length, respectively. Two NTS genotypes (WAN 1, WAN 2) were detected from 2 geographical isolates (GOM, WAN 1), which differed from each other by a single substitution. Sequence divergences between Korean Perkinsus and other Perkinsus species for each of the NTS and ITS-5.8S loci are shown in Tables $3 \& 4$, respectively. The sequences reported here have been deposited in GenBank (Accession Numbers AF473840 \& AF438150 for NTS and ITS-5.8S, respectively).

The NTS sequence of the Korean Perkinsus showed approximately 99.91 to $100 \%$ similarity to P. atlanticus, with only a single base substitution, and 99.91\% sequence similarity. The sequence was also very similar to that of $P$. olseni; the mean pairwise sequence comparison showed $98.12 \%$ similarity. However, the NTS sequence of Korean Perkinsus showed pronounced sequence divergence from those reported in other Perkinsus lineages; we observed mean sequence divergence of $26.94 \%$ between Korean isolates and $P$. marinus (Table 3). The degree of sequence divergence among various Perkinsus lineages in the
ITS-5.8S rRNA region was relatively low, compared to the NTS region. Nucleotide sequences of Korean Perkinsus for each of the ITS 1, ITS 2 and 5.8S rRNA regions were $100 \%$ identical to those of $P$. atlanticus and Japanese Perkinsus isolates. The ITS-5.8S rRNA sequence of Korean Perkinsus also showed high similarity to those of P. olseni (99.86\%) and Thai Perkinsus species (SP 4) (99.72\%). In contrast, the sequence divergence of the ITS-5.8S region between Korean Perkinsus and P. qugwadi was pronounced (35.04\%), while the sequence difference between Korean Perkinsus and P. marinus was $6.27 \%$ (Table 4).

\section{In vitro sporulation pattern}

The zoosporulation pattern observed in Korean Perkinsus isolates is illustrated in Fig. 3. After $2 \mathrm{~d}$ in aerated seawater at $25^{\circ} \mathrm{C}$, large lipid droplets that were commonly observed among hypnospores had disappeared and the nucleus had become extremely enlarged. Successive karyokinesis and cytokinesis resulted

Table 3. Mean uncorrected pairwise distance ( $P$; below diagonal) and percent similarity (above diagonal) of non-transcribed spacer (NTS) sequences among Perkinsus spp. (for abbreviations, see Table 2)

\begin{tabular}{|lccccccccc|}
\hline & WAN 1 & WAN 2 & GOM & ATL & OLS & MAR & AND & SP 1 & SP 4 \\
\hline WAN 1 & & 99.91 & 100.00 & 100.00 & 98.15 & 73.14 & 61.88 & 62.62 & 97.03 \\
WAN 2 & 0.0009 & & 99.91 & 99.91 & 98.06 & 73.05 & 61.8 & 62.53 & 96.94 \\
GOM & 0.0000 & 0.0009 & & 100.00 & 98.15 & 73.07 & 61.91 & 62.56 & 97.03 \\
ATL & 0.0000 & 0.0009 & 0.0000 & & 98.15 & 73.07 & 61.91 & 62.56 \\
OLS & 0.0185 & 0.0194 & 0.0185 & 0.0185 & & 73.31 & 61.51 & 62.39 & 97.63 \\
MAR & 0.2686 & 0.2695 & 0.2693 & 0.2693 & 0.2669 & & 58.12 & 57.82 \\
AND & 0.3812 & 0.382 & 0.3809 & 0.3809 & 0.3849 & 0.4188 & & 81.08 \\
SP 1 & 0.3738 & 0.3747 & 0.3744 & 0.3744 & 0.3761 & 0.4218 & 0.1892 & 59.96 \\
SP 4 & 0.0297 & 0.0306 & 0.0297 & 0.0297 & 0.0235 & 0.2715 & 0.4004 & 0.3769 \\
\hline
\end{tabular}


Table 4. Mean uncorrected pairwise distance ( $P$; below diagonal) and percent similarity (above diagonal) of internal transcribed spacer (ITS) and 5.8S rRNA sequences among Perkinsus spp. (for abbreviations, see Table 2)

\begin{tabular}{|c|c|c|c|c|c|c|c|c|c|c|c|c|c|}
\hline & WAN 1 & WAN 2 & GOM & ATL & JAP & OLS & MAR & AND & QUG & SP 1 & SP 2 & SP 3 & SP 4 \\
\hline WAN 1 & & 100.00 & 100.00 & 100.00 & 100.00 & 99.86 & 93.73 & 87.37 & 64.96 & 87.33 & 87.48 & 93.01 & 99.72 \\
\hline WAN 2 & 0.0000 & & 100.00 & 100.00 & 100.00 & 99.86 & 93.73 & 87.37 & 64.96 & 87.33 & 87.48 & 93.01 & 99.72 \\
\hline GOM & 0.0000 & 0.0000 & & 100.00 & 100.00 & 99.86 & 93.73 & 87.37 & 64.96 & 87.33 & 87.48 & 93.01 & 99.72 \\
\hline ATL & 0.0000 & 0.0000 & 0.0000 & & 100.00 & 99.86 & 93.73 & 87.37 & 64.96 & 87.33 & 87.48 & 93.01 & 99.72 \\
\hline JAP & 0.0000 & 0.0000 & 0.0000 & 0.0000 & & 99.86 & 93.73 & 87.37 & 64.96 & 87.33 & 87.48 & 93.01 & 99.72 \\
\hline OLS & 0.0014 & 0.0014 & 0.0014 & 0.0014 & 0.0014 & & 93.87 & 87.53 & 65.11 & 87.47 & 87.62 & 93.15 & 99.86 \\
\hline MAR & 0.0627 & 0.0627 & 0.0627 & 0.0627 & 0.0627 & 0.0613 & & 87.37 & 65.60 & 87.61 & 87.76 & 99.31 & 93.72 \\
\hline AND & 0.1263 & 0.1263 & 0.1263 & 0.1263 & 0.1263 & 0.1247 & 0.1263 & & 63.15 & 95.93 & 96.06 & 86.65 & 87.39 \\
\hline QUG & 0.3504 & 0.3504 & 0.3504 & 0.3504 & 0.3504 & 0.3489 & 0.3440 & 0.3685 & & 63.63 & 63.48 & 64.85 & 64.96 \\
\hline SP 1 & 0.1267 & 0.1267 & 0.1267 & 0.1267 & 0.1267 & 0.1253 & 0.1239 & 0.0407 & 0.3637 & & 99.72 & 86.89 & 87.33 \\
\hline SP 2 & 0.1252 & 0.1252 & 0.1252 & 0.1252 & 0.1252 & 0.1238 & 0.1224 & 0.0394 & 0.3652 & 0.0028 & & 87.03 & 87.48 \\
\hline SP 3 & 0.0699 & 0.0699 & 0.0699 & 0.0699 & 0.0699 & 0.0685 & 0.0069 & 0.1335 & 0.3515 & 0.1311 & 0.1297 & & 93.01 \\
\hline SP 4 & 0.0028 & 0.0028 & 0.0028 & 0.0028 & 0.0028 & 0.0014 & 0.0628 & 0.1261 & 0.3504 & 0.1267 & 0.1252 & 0.0699 & \\
\hline
\end{tabular}
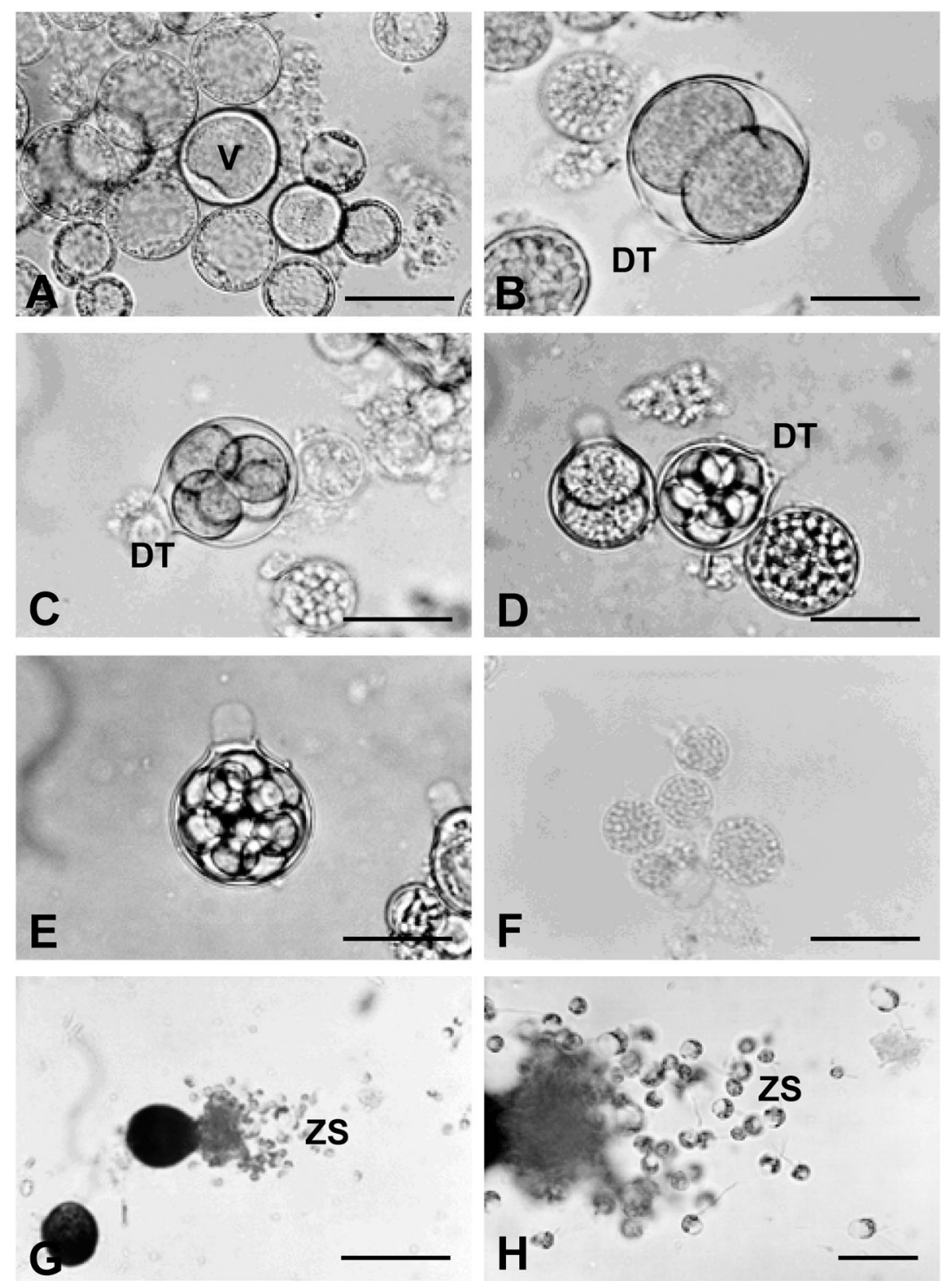

in the formation of $2,4,8,16$, or 32 cells inside the hypnospore. After 3 to $4 \mathrm{~d}$ of incubation, a pore was observed on the surface of the hypnospores as early as during the 2-cell stage, which later formed a discharge tube. Although some hypnospores required 3 to $4 \mathrm{~d}$ of incubation prior to successive cell divisions, most of them started cell division within 2 to $3 \mathrm{~d}$ in aerated seawater. Swimming zoospores released via the discharge tube from mature hypnospores were observed 4 to $5 \mathrm{~d}$ after incubation. Zoospores were estimated as having a mean $( \pm \mathrm{SD})$ head diameter of $4.55 \pm 0.90 \mu \mathrm{m}$ and a flagellar length of $8.12 \pm 1.03 \mu \mathrm{m}$ (Table 5).

\section{DISCUSSION}

Due to its sub-lethal impacts on some commercially important marine molluscs, Perkinsus has received much attention since its first discovery in the early 1950s. Secretion of extracellular

Fig. 3. In vitro sporulation of Perkinsus sp. in GF/C-filtered seawater: (A) beginning of eccentric vacuole subdivision (400x); (B) 2-cell stage $(400 \times) ;(C) 4$-cell stage $(400 \times)$; (D) 8-cell stage $(400 \times)$; (E) 16-cell stage $(400 \times)_{i}(\mathrm{~F})$ stage with hundreds of zoospores (200×); (G) releasing zoospores $(200 \times) ;(\mathrm{H})$ releasing zoospores $(1000 \times)$. $\mathrm{V}$ : vacuole; DT: discharging tube; ZS: zoospores. Scale bars: $A$ to $E=50 \mu \mathrm{m}$, $\mathrm{F}$ and $\mathrm{G}=100 \mu \mathrm{m}, \mathrm{H}=10 \mu \mathrm{m}$ 
Table 5. Zoospore size (mean \pm SD) among Perkinsus spp.

\begin{tabular}{|c|c|c|c|c|}
\hline Species & Host & Body $(\mu \mathrm{m})$ & $\begin{array}{l}\text { Flagellum } \\
\qquad(\mu \mathrm{m})\end{array}$ & Source \\
\hline Perkinsus sp. & $\begin{array}{c}\text { Ruditapes } \\
\text { philippinarum }\end{array}$ & $4.55 \pm 0.90$ & $8.12 \pm 1.03$ & Present study \\
\hline P. atlanticus & R. decussatus & $4.5 \pm 0.6$ & $12.7 \pm 2.4$ & Azevedo (1989) \\
\hline P. qugwadi & $\begin{array}{c}\text { Patinopecten } \\
\text { yessoensis }\end{array}$ & $4.5 \pm 1.0$ & $9.67 \pm 2.07$ & $\begin{array}{l}\text { Blackbourn } \\
\text { et al. (1998) }\end{array}$ \\
\hline Perkinsus sp. & Macoma balthica & $4-6$ & - & Perkins (1996) \\
\hline Perkinsus sp. & Tagelus plebeius & 4 & - & $\begin{array}{c}\text { Dungan et al. } \\
(2002)\end{array}$ \\
\hline P. atlanticus & R. decussatus & $3.69 \pm 0.05$ & - & $\begin{array}{c}\text { Casas et al. } \\
(2002)\end{array}$ \\
\hline
\end{tabular}

products and continuous energy drain by Perkinsus degrade defence activity (Choi et al. 1989, Garreis et al. 1996, Chu et al. 2000), retard the growth and reproduction and increase the mortality of the host (Ray 1954, Menzel \& Hopkins 1955, Paynter \& Burreson 1991, Choi et al. 1994). Perkinsosis, a disease caused by Perkinsus spp., has been classified by the Office International des Epizooties (OIE) as a disease that warrants notification.

Perkinsus-like parasitic organisms were first reported in Korean waters in 1997 from Manila clams (Ruditapes philippinarum); hypnospore development in FTM and microscopic features of the trophozoite indicated that these parasites were a species of Perkinsus (Choi \& Park 1997). According to Park \& Choi (2001), Perkinsus sp. is epidemic along the western and southern coasts of Korea, and its prevalence and infection intensity vary from approximately 0 to $100 \%$ and 12 to 3924309 cells g ${ }^{-1}$ tissue, respectively. Heavily infected clams often exhibit nodules on their gills and mantle tissues; these clams also show necrosis in various organs, suggesting that the mass mortalities of clams observed in Korean waters are closely associated with high levels of infection (Park \& Choi 2001).

In the present study, sequence analyses of the NTS and the ITS-5.8S rRNA genes provided significant insight into the determination of species identity and phylogenetic affinity of Korean Perkinsus. A high degree of sequence divergence was observed between Korean Perkinsus isolates and other congeneric species, including $P$. marinus and $P$. andrewsi, while minor sequence differentiation was found between Korean Perkinsus and Japanese Perkinsus, P. atlanticus and $P$. olseni. The mean uncorrected pairwise distance $(P)$ of the NTS sequence of Korean Perkinsus deviated from those of $P$. marinus, $P$. andrewsi and SP 1 (North American isolate, see Table 2) by 26.94, 37.98 and $37.33 \%$, respectively. Several studies on the molecular phylogenetic affinities of Perkinsus spp. have reported similar results (Hamaguchi et al. 1998, Kotob et al. 1999a, Robledo et al. 2000, Murrell et al. 2002, Leethochavalit et al. 2003). The ITS-5.8S rRNA sequence of Korean Perkinsus was $100 \%$ identical to that of Perkinsus sp. isolated from Ruditapes philippinarum collected in Kumamoto and Hiroshima, Japan (Hamaguchi et al. 1998).

To infer phylogenetic relationships among various Perkinsus species, we performed comparative phylogenetic analysis. A bootstrapped, unrooted NJ phylogram was constructed based on the NTS sequences of Perkinsus. The phylogram showed close phylogenetic ties between Korean Perkinsus, $P$. atlanticus and P. olseni (Fig. 4). In the phylogram, Korean Perkinsus isolates and European $P$. atlanticus formed a robust clade, with a bootstrap support value of $100 \%$. Monophyletic grouping between the Korean-European Perkinsus clade and the $P$. olseni-SP 4 clade was evident in the phylogram, with a bootstrap value of $100 \%$. Use of the MP criterion did not alter the tree topology constructed using NJ (Fig. 4). A close phylogenetic relationship between $P$. atlanticus and Korean isolates was also demonstrated by NJ and MP phylogenetic methods (not shown), using an independent ITS dataset of Perkinsus species. These results strongly suggest that the Perkinsus sp. extracted from Manila clams in Korean waters is $P$. atlanticus, which is present in European waters and/or is closely related to $P$. olseni, which is infecting a wide

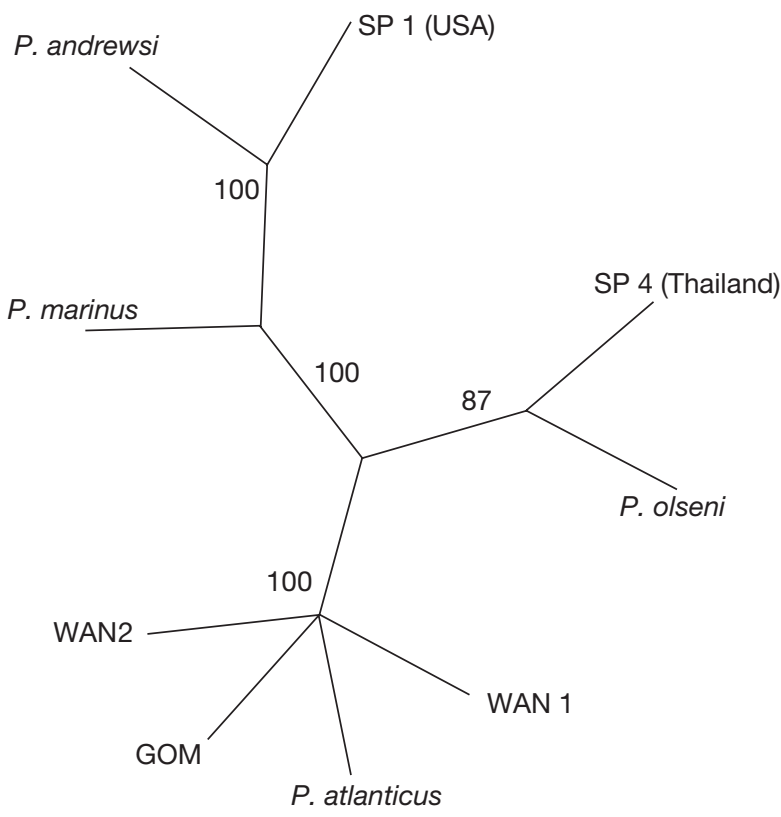

Fig. 4. Unrooted neighbour-joining (NJ) tree (based on HKY distances), bootstrapped with 1000 replicates for the Perkinsus NTS dataset. Numbers on branches represent bootstrap values for each node 
range of abalones and marine bivalves on the south and the west coasts of Australia and the Gulf of Thailand (Goggin \& Lester 1987, 1995, Leethochavalit et al. 2004). Comparing nucleotide sequences of the ITS-5.8S rRNA region, Hamaguchi et al. (1998) reported that the Perkinsus sp. found in Japan may be $P$. atlanticus or a closely related species. Based on the sequence similarity between $P$. atlanticus and Australian isolates (i.e. $P$. atlanticus-P. olseni, $P$. atlanticus-unidentified $P$. atlanticus-like isolate), Robledo et al. (2000) suggested that these 3 geographic isolates constitute a single species or a subgroup of Perkinsus species with a wide geographic distribution. Murrell et al. (2002) sequenced NTS loci of P. olseni and compared these sequences to known Perkinsus sequences. Since the NTS sequences of $P$. olseni were very close to those of $P$. atlanticus, they proposed that $P$. atlanticus should be synonymised with $P$. olseni.

In addition to the ITS regions (ITS 1 and ITS 2), the NTS region is among the most common molecular markers used to characterise the genetic structure of a population or to determine the taxonomic position of morphologically complex cryptic species, including Perkinsus species. Based on sequence variations in the NTS region among different species, a novel PCRbased molecular marker for correct species identification is available for some Perkinsus groups. Robledo et al. (1998) and Park et al. (2002) developed PCRbased NTS markers for $P$. marinus- and $P$. atlanticusspecific diagnosis, respectively. The NTS region is known to accumulate a high degree of sequence variability, even between closely related species, since the nucleotides are not transcribed (Marsh et al. 1995). Robledo et al. (1999) reported that NTS sequences of $P$. marinus varied with geography, even though the ITS regions were identical. Interestingly, the nucleotide sequence of the NTS region of the Korean Perkinsus sp. is 99.91 to $100 \%$ identical to that of $P$. atlanticus found in European waters, despite the wide geographical distance between these 2 isolates.

Incidences of Perkinsus in European waters date back to the late 1960s. Alderman \& Gras (1969) reported the occurrence of a Perkinsus-like organism in oysters from the Atlantic and Mediterranean coasts of France. Da Ros \& Canzonier (1985) reported Perkinsus infections in the carpet clam Venerupis decussata (=Ruditapes decussatus) and the flat oyster Ostrea edulis collected from Italy in 1978. Based upon transmitted electron microscopy (TEM), Azevedo (1989) identified Perkinsus isolated from the carpet clam $R$. decussatus in Portuguese waters as P. atlanticus. Subsequently, $P$. atlanticus infections among venerid clams have been reported from Portugal, Spain, France, Italy and Ireland (Azevedo 1989, Figueras et al. 1992, Almeida et al. 1999, Canestri-Trotti et al.
2000). However, it is uncertain whether Perkinsus is endemic to the Atlantic or the Mediterranean, or whether it was introduced from elsewhere. According to Flassch \& Leborgne (1992), Manila clams in European waters were originally transplanted from the Pacific coast of North America in the early 1970s. Manila clams are endemic to the Yellow Sea (Goulletquer 1997), and they were accidentally introduced to the Pacific coast of North America in the 1930s from Japan, when the Pacific oyster Crassostrea gigas was transplanted for commercial purposes (Quayle 1964). However, there have been no reports of the occurrence of Perkinsus infections in Manila clam populations along the north-eastern Pacific coast. Thus, it is unlikely that $P$. atlanticus in Europe was introduced from the Pacific coast of North America. Alternatively, we speculate that the high degree of affinity between the NTS and the ITS-5.8S rRNA genes of $P$. atlanticus in Europe and Perkinsus in Korea may be coupled with anthropogenic activities between Europe and Asia, such as ballast-water discharge from maritime vessels or transfer of infected molluscs from one place to another, although evidence to support these hypotheses is currently unavailable.

In conclusion, our molecular sequence data (NTS, ITS 1, ITS 2 and 5.8S) in addition to morphological features, such as life stage, zoosporulation pattern and zoospore size suggest that the Perkinsus sp. found in Manila clams (Ruditapes philippinarum) in Korean waters is $P$. atlanticus and/or $P$. olseni. However, considering the taxonomic priority of $P$. olseni, we conclude that Korean Perkinsus sp. is P. olseni (atlanticus).

Acknowledgements. The authors thank the staff of the Shellfish Aquaculture and Research Laboratory, Cheju National University, for their help in data acquisition and analysis. We also thank Dr. S. M. Bower of Pacific Biological Station, Canada, for review and comments on the early manuscript. This study was supported by a Korea Research Foundation Grant (KRF-2003-042-F00006).

\section{LITERATURE CITED}

Alderman DJ, Gras P (1969) 'Gill disease' of Portuguese oysters. Nature 224:408-409

Almeida M, Berthe F, Thébault A, Dinis MT (1999) Whole clam culture as a quantitative diagnostic procedure of Perkinsus atlanticus (Apicomplexa, Perkinsea) in clams Ruditapes decussatus. Aquaculture 177:325-332

Azevedo C (1989) Fine structure of Perkinsus atlanticus n. sp. (Apicomplexa, Perkinsea) parasite of the clam Ruditapes decussatus from Portugal. J Parasitol 75:627-635

Azevedo C, Corral L, Cachola R (1990) Fine structure zoosporulation in Perkinsus atlanticus (Apicomplexa: Perkinsea). Parasitology 100:351-358

Blackbourn J, Bower SM, Meyer GR (1998) Perkinsus qugwadi sp. nov. (incertae sedis), a pathogenic protozoan parasite 
of Japanese scallops, Patinopecten yessoensis, cultured in British Columbia, Canada. Can J Zool 7:942-953

Canestri-Trotti G, Baccarni EM, Paesanti F, Turolla E (2000) Monitoring of infections by Protozoa of the genera Nematopsis, Perkinsus and Porospora in the smooth venus clam Callista chione from the North-Western Adriatic Sea (Italy). Dis Aquat Org 42:157-161

Casas SM, Villalba A, Reece KS (2002) Study of perkinsosis in the carpet shell clam Tapes decussates in Galicia (NW Spain). I. Identification of the aetiological agent and in vitro modulation of zoosporulation by temperature and salinity. Dis Aquat Org 50:51-65

Casas SM, Grau A, Reece KS, Apakupakul K, Azevedo C, Villalba A (2004) Perkinsus mediterraneus n. sp., a protistan parasite of the European flat oyster Ostrea edulis from the Balearic Islands, Mediterranean Sea. Dis Aquat Org 58: 231-244

Castresana J (2000) Selection of conserved blocks from multiple alignments for their use in phylogenetic analysis. Mol Biol Evol 17:540-552

Choi DL, Kwon JN, Park SW (1998) Infection and rapid detection of Perkinsus sp. in cultured baby neck clam, Ruditapes philippinarum from western coast of Korea. Korean J Fish Pathol 11:69-76 (in Korean with English abstract)

Choi KS, Park KI (1997) Report on the occurrence of Perkinsus sp. in the Manila clams, Ruditapes philippinarum, in Korea. J Aquacult 10:227-237

Choi KS, Wilson EA, Lewis DH, Powell EN, Ray SM (1989) The energetic cost of Perkinsus marinus parasitism in oysters: quantification of the thioglycollate method. J Shellfish Res 8:125-131

Choi KS, Powell EN, Lewis DH, Ray SM (1994) Instantaneous reproductive effort in female American oysters, Crassostrea virginica, measured by a new immunoprecipitation assay. Biol Bull (Woods Hole) 186:41-61

Choi KS, Park KI, Lee KW, Matsuoka K (2002) Infection intensity, prevalence and histopathology of Perkinsus sp. in the Manila clam, Ruditapes philippinarum, in Isahaya Bay, Japan. J Shellfish Res 21:119-125

Chu FLE, Soudant P, Volety K, Huang Y (2000) Uptake and interconversion of fluorescent lipid analogs in the protozoan parasite, Perkinsus marinus, of the oyster, Crassostrea virginica. Exp Parasitol 95:240-251

Chung EY, Hur SB, Hur YB, Lee JS (2001) Gonadal maturation and artificial spawning of the Manila clam Ruditapes philippinarum (Bivalvia: Veneridae), in Komso Bay, Korea. J Fish Sci Technol 4:208-218

Coss CA, Robledo JA, Ruiz GM, Vasta GR (2001) Description of Perkinsus andrewsi n. sp. isolated from the Baltic clam (Macoma balthica) by characterization of the ribosomal RNA locus, and development of a species-specific PCRbased diagnostic assay. J Eukaryot Microbiol 48:52-61

Da Ros L, Canzonier WJ (1985) Perkinsus, a protistan threat to bivalve culture in the Mediterranean basin. Bull Eur Assoc Fish Pathol 5:23-27

Dungan CF, Hamilton RM, Hudson KL, McCollough CB, Reece KS (2002) Two epizootic diseases in Chesapeake commercial clams, Mya arenaria and Tagelus plebeius. Dis Aquat Org 50:67-78

Figueras A, Robledo JAF, Novoa B (1992) Occurrence of haplosporidian and Perkinsus-like infections in carpet-shell clams, Ruditapes decussatus (Linnaeus, 1758), of the Ría de Vigo (Galicia, NW Spain). J Shellfish Res 11:377-382

Figueras A, Lorenzo G, Ordas MC, Gouy M, Novoa B (2000) Sequence of the small subunit ribosomal RNA gene of Perkinsus atlanticus-like isolates from carpet shell clam in Galicia, Spain. Mar Biotechnol 2:419-428
Flassch JP, Leborgne Y (1992) Introduction in Europe, from 1972 to 1980, of the Japanese Manila clam (Tapes philippinarum) and the effects on aquaculture production and natural settlement. ICES Mar Sci Symp 194:92-96

Garreis KA, La Peyre JF, Faisal M (1996) The effects of Perkinsus marinus extracellular products and purified proteases on oyster defence parameters in vitro. Fish Shellfish Immunol 6:581-597

Goggin CL, Barker SC (1993) Phylogenetic position of the genus Perkinsus (Protista, Apicomplexa) based on small subunit ribosomal RNA. Mol Biochem Parasitol 60:65-70

Goggin CL, Lester RJG (1987) Occurrence of Perkinsus species (Protozoa, Apicomplexa) in bivalves from the Great Barrier Reef. Dis Aquat Org 3:113-117

Goggin CL, Lester RJG (1995) Perkinsus, a protistan parasite of abalone in Australia: a review. Aust J Mar Freshw Res 46:639-646

Goulletquer P (1997) A biography of the Manila clam Tapes philippinarum. RIDRV-97.02/RA/, IFREMER, La Tremblade

Hamaguchi MN, Suzuki N, Usuki H, Ishioka H (1998) Perkinsus protozoan infection in short-necked clam Tapes (=Ruditapes) philippinarum in Japan. Fish Pathol 33: 473-480

Kotob SL, McLaughlin SM, Van Berkum P, Faisal M (1999a) Discrimination between two Perkinsus spp. isolated from the softshell clam, Mya arenaria, by sequence analysis of two internal transcribed spacer regions and the 5.8S ribosomal RNA. Parasitology 119:363-368

Kotob SL, McLaughlin SM, Van Berkum P, Faisal M (1999b) Characterization of two Perkinsus spp. from the softshell clam, Mya arenaria, using the small subunit ribosomal RNA gene. J Eukaryot Microbiol 46:439-444

Lee YH, Chang YJ, Lim HK, Chung GS (1996) Comparison of growth and survival rate in shortnected clams, Ruditapes philippinarum, from different seeding production area. J Aquacult 9:223-232

Leethochavalit L, Upatham ES, Choi KS, Sawangwong P, Chalermwat K, Kruatrachue M (2003) Ribosomal RNA characterization of non-transcribed spacer and two internal transcribed spacers with 5.8S ribosomal RNA of Perkinsus sp. found in undulated surf clams (Paphia undulata) from Thailand. J Shellfish Res 22:431-434

Leethochavalit S, Chalermwat K, Upatham ES, Choi KS, Sawangwong P, Kruatrachue M (2004) The occurrence of Perkinsus sp. in undulated surf clams, Paphia undulata, from the Gulf of Thailand. Dis Aquat Org 60:165-171

Lester RJG, Davis GHG (1981) A new Perkinsus species (Apicomplexa, Perkinsea) from the abalone Haliotis ruber. J Invertebr Pathol 37:181-187

Liang YB, Zhang XC, Wang LJ, Yang B, Zhang Y, Cai CL (2001) Prevalence of Perkinsus sp. in the Manila clam, Ruditapes philippinarum, along the northern coast of the Yellow Sea in China. Oceanol Limnol Sinica 32:502-511 (in Chinese with English abstract)

Mackin JG, Ray SM (1954) Studies on the effects of infection by Dermocystidium marinum on cilary action in oysters (Crassostrea virginica). Proc Natl Shellfish Assoc 45: 168-181

Mackin JG, Owen HM, Collier A (1950) Preliminary note on the occurrence of a new protistan parasite, Dermocystidium marinum n. sp., in Crassostrea virginica (Gemlin). Science 111:328-329

Marsh AG, Gauthier JD, Vaster GR (1995) A semiquantitative PCR assay for assessing Perkinsus marinus infections in the eastern oyster, Crassostrea virginica. J Parasitol 81: 577-583 
McLaughlin SM, Tall BD, Shaheen A, Elsayed EE, Faisal M (2000) Zoosporulation of a new Perkinsus species isolated from the gills of the softshell clam Mya arenaria. Parasite $7: 115-122$

Menzel RW, Hopkins SH (1955) The growth of oysters parasitized by the fungus Dermocystidium marinum and by the trematode Bucelphalus cuculus. J Parasitol 41:333-342

Murrell A, Kleeman SN, Barker SC, Lester RJG (2002) Synonymy of Perkinsus olseni Lester \& Davis, 1981 and Perkinsus atlanticus Azevedo, 1989 and an update on the phylogenetic position of the genus Perkinsus. Bull Eur Assoc Fish Pathol 22:258-265

Ordás MC, Figueras A (1998) In vitro culture of Perkinsus atlanticus, a parasite of the carpet shell clam Ruditapes decussates. Dis Aquat Org 33:129-136

Park KI, Choi KS (2001) Spatial distribution and infection intensity of the protozoan parasite Perkinsus sp. in the Manila clam Ruditapes philippinarum in Korea. Aquaculture 203:9-22

Park KI, Park YM, Lee J, Choi KS (2002) Development of PCR assay for detection of the protozoan parasite Perkinsus in Korea. Korean J Environ Biol 20:109-117 (in Korean with English abstract)

Paynter KT, Burreson EM (1991) Effects of Perkinsus marinus infection in the eastern oyster, Crassostrea virginica. II. Disease development and impact on growth rate at different salinities. J Shellfish Res 2:425-431

Perkins FO (1969) Ultrastructure of vegetative stages in Labyrinthomyxa marina (=Dermocystidium marinum), a commercially significant oyster pathogens. J Invertebr

Editorial responsibility: Albert Sparks,

Seattle, Washington, USA
Pathol 13:199-222

Quayle DB (1964) Distribution of introduced marine Mollusca in British Columbia waters. J Fish Res Board Can 21: 1155-1181

Ray SM (1954) Studies of pathogenesis of Dermocystidium marinum. Proc Natl Shellfish Assoc 45:164-167

Reece KS, Bushek D, Graves JE (1997) Molecular markers for population genetic analysis of Perkinsus marinus. Mol Mar Biol Biotechnol 6:197-206

Robledo JAF, Gauthier JD, Coss CA, Wright AC, Vasta GR (1998) Species-specificity and sensitivity of a PCR-based assay for Perkinsus marinus in the eastern oyster, Crassostrea virginica: a comparison with the fluid thioglycollate assay. J Parasitol 84:1237-1244

Robledo JA, Wright AC, Marsh AG, Vasta GR (1999) Nucleotide sequence variability in the nontranscribed spacer of the rRNA locus in the oyster parasite Perkinsus marinus. J Parasitol 85:650-656

Robledo JAF, Coss CA, Vasta GB (2000) Characterization of the ribosomal RNA locus of Perkinsus atlanticus, and development of a polymerase chain reaction-based diagnostic assay. J Parasitol 86:972-978

Swofford DL (1998) PAUP*: phylogenetic analysis using parsimony and other methods, ver. 4.0 beta. Sinauer, Sunderland, MA

Thompson JD, Higgins DG, Gibson TJ (1994) Clustal W: improving the sensitivity of progressive multiple sequence alignment through sequence weighting, position-specific gap penalties and weight matrix choice. Nucleic Acids Res 22:4673-4680

Submitted: September 18, 2004; Accepted: April 4, 2005 Proofs received from author(s): September 15, 2005 